\title{
A new species of Tortanus (Atortus) (Copepoda: Calanoida: Tortanidae) from the Seychelles, Mauritius and Madagascar
}

\author{
Susumu Ohtsuka* ${ }^{\ddagger}$ and David V.P. Conway ${ }^{\dagger}$ \\ *Takehara Marine Science Station, Setouchi Field Science Center, Graduate School of Biosphere Science, Hiroshima University, \\ 5-8-1 Minato-machi, Takehara, Hiroshima 725-0024, Japan. \\ ${ }^{\dagger}$ Marine Biological Association of the United Kingdom, The Laboratory, Citadel Hill, Plymouth, Devon, PL1 2PB, UK. \\ ${ }^{\ddagger}$ Corresponding author, e-mail: ohtsuka@hiroshima-u.ac.jp
}

\begin{abstract}
A new species of the planktonic copepod Tortanus (Atortus) (Calanoida: Tortanidae), T. (A.) magnonyx is described from the Seychelles, Mauritius and Madagascar. This is the sixth species of the Indian Ocean recticauda species group, of the Indo-West Pacific recticauda species complex, that has been described from the western Indian Ocean. The inshore areas where these copepods are found have been poorly surveyed, so the number of species found implies a high diversity.
\end{abstract}

\section{INTRODUCTION}

The inshore zooplankton of the islands of Mahé (Seychelles) and Rodrigues (Mauritius) was sampled during a long-term biodiversity study (Burnett et al., 2001; Conway et al., 2003). While collecting live material in a shallow bay in the north-west of the island of Mahé, where routine sampling was not normally carried out, a new species of the predatory, planktonic, calanoid copepod Tortanus (Atortus) was discovered. Subsequent opportunistic sampling in bays in Mauritius and Madagascar yielded further specimens of this same new species, which has been named T. (A.) magnonyx and is described herein. This is the sixth species of the Indian Ocean recticauda species group, assigned to the Indo-West Pacific recticauda species complex: T. (A.) recticauda (Giesbrecht, 1889) from the Red Sea and the Arabian Gulf; T. (A.) capensis Grindley, 1978 from South Africa; T. (A.) ampliramus Ohtsuka et al., 2000 from the northern Red Sea; T. (A.) nishidai Ohtsuka et al., 2000 from the Gulf of Aden; T. (A.) insularis Ohtsuka \& Conway, 2003 from Rodrigues. To date, the West Pacific murrayi group of the same species complex also accommodates six species (Ohtsuka \& Kimoto, 1989; Ohtsuka \& Reid, 1998). The number of species of the recticauda species group that have been found in the western Indian Ocean, from the Red Sea to South Africa, implies a high species diversity.

\section{MATERIALS AND METHODS}

Zooplankton samples were collected on foot with a $0.3 \mathrm{~m}$ diameter hand net (mesh aperture $100 \mu \mathrm{m}$ ), 10-20 $\mathrm{m}$ off the beach in Baie Ternay, Mahé, Seychelles (Figure 1). This narrow bay is sheltered and highly productive, with a bottom of fine sand and silt. Further zooplankton was similarly sampled 10-30 m off the beach in a semi-enclosed, eutrophic, muddy lagoon $2 \mathrm{~km}$ south of Mahebourg, south-eastern Mauritius. Additionally, samples were collected from Île Sainte Marie (Nosy

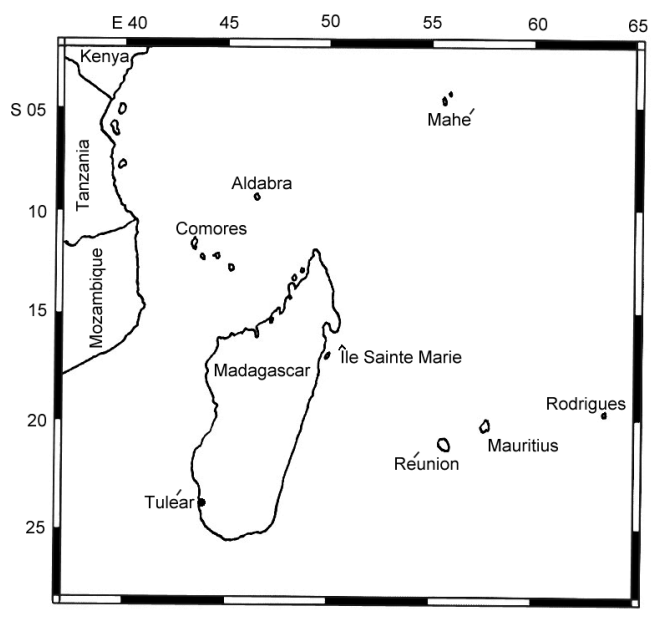

Figure 1. The sampling locations in the south-western Indian Ocean.

Boraha), Madagascar, by streaming the same net in the tidal current as it passed beneath the centre of the causeway that spans the narrow entrance to Baie des Forbans, in the central west of the island. All these bays were within fringing coral reefs.

Samples were preserved in $4 \%$ borax buffered formalin immediately after collection. The samples were later sorted for Tortanus specimens, which were subsequently dissected and observed in lactophenol with a differential interference microscope (Nikon Optiphoto). Appendages of dissected specimens were mounted on glass slides and sealed with CMC-10 (Masters Inc., Ltd).

Since the morphology of appendages is very similar to that of other previously, well-described congeners, only differences are described herein. Terminology follows Huys \& Boxshall (1991). Type specimens are deposited in the Natural History Museum (NHM), London. 


\section{SYSTEMATICS}

Family TORTANIDAE G.O. Sars, 1902

Genus Tortanus Giesbrecht, 1898

Tortanus (Atortus) magnonyx sp. nov.

(Figures 2 \& 3)

\section{Type material}

Six females (total length range $2.17-2.25 \mathrm{~mm}$, mean $2.22 \mathrm{~mm}, \mathrm{SD} \pm 0.032$ ) and four males (total length range $1.89-1.93 \mathrm{~mm}$, mean $1.90, \mathrm{SD} \pm 0.020$ ), collected from Baie Ternay, Mahé, Seychelles $\left(04^{\circ} 38.3^{\prime} \mathrm{S} \quad 55^{\circ} 22.8^{\prime} \mathrm{E}\right.$; 0.5-1.5 m depth), between 17 and 27 September 2002.

Holotype: one female, partly dissected and mounted on eight glass slides, body proper in vial, NHM 2004.2737.

Allotype: one male, partly dissected and mounted on one glass slide, body proper in vial, NHM 2004.2738.

Paratypes: one female and one male, partly dissected and mounted on two glass slides, bodies proper in vial, NHM 2004.2739-40; four females and two males, whole specimens in vial, NHM 2004.2741-46.

\section{Non-type material}

Eleven females (total length range $2.31-2.49 \mathrm{~mm}$, mean $2.40 \mathrm{~mm}, \mathrm{SD} \pm 0.055)$ and seven males (total length range 2.09-2.20 mm, mean $2.12 \mathrm{~mm}, \mathrm{SD} \pm 0.037$ ), collected from a lagoon south of Mahebourg, Mauritius $\left(20^{\circ} 25.1^{\prime} \mathrm{S}\right.$ $57^{\circ} 41.9^{\prime} \mathrm{E}$; $0.5-1.0 \mathrm{~m}$ depth), on 11 October 2002, whole specimens in vial NHM 2004.2747-64.

Ten females (total length range $2.20-2.31 \mathrm{~mm}$, mean $2.27 \mathrm{~mm}, \mathrm{SD} \pm 0.040$ ) and ten males (total length range 1.79-1.94 mm, mean $1.88 \mathrm{~mm}, \mathrm{SD} \pm 0.049$ ), collected from Baie des Forbans, Île Sainte Marie, Madagascar $\left(17^{\circ} 00.4^{\prime} \mathrm{S}\right.$ $49^{\circ} 50.5^{\prime} \mathrm{E}$; $0.5-3 \mathrm{~m}$ depth), between 15 and 30 April 2003, whole specimens in vial NHM 2004.2765-84.

\section{Description of adult female}

Body (Figure 2A,B) with prosome approximately 3.5 times as long as urosome; cephalosome separate from first pediger, protruded anteriorly into round expansion in which naupliar eyes involved and strongly grooved at dorsal mid-length; pedigers 4 and 5 completely fused; posterior prosome slightly asymmetrical, with right side more swollen (Figure 2A). Urosome (Figure 2A-H) asymmetrical; genital compound-somite (Figure 2A-H) highly asymmetrical, expanded anterolaterally, bluntly produced posterolaterally on right side; right dorsolateral swelling with claw-like process directed ventrally, tip of which not reaching to posterior end of somite; process bearing fine setule at tip; genital operculum (Figure $2 \mathrm{H}$ ) located on protrusion at point of swelling; anal somite short; caudal rami (Figure 2A,C\&D) asymmetrical, left ramus larger and wider than right, constricted at base; caudal seta I rudimentary, right $\mathrm{V}$ proximally thick; inner margins of rami furnished with long setules except for anterior one-third.

Antennule reaching slightly beyond posterior end of caudal rami excluding setae; segmentation and setation as in others of subgenus (cf. Ohtsuka \& Reid, 1998). Antenna to maxillule as in T. (A.) ryukyuensis Ohtsuka \& Kimoto, 1989 (see figures $2 \& 3$ in Ohtsuka \& Kimoto, 1989). Maxilla as in T. (A.) ampliramus (figure $1 \mathrm{H}$ in Ohtsuka et al., 2000); basis with two rudimentary elements in addition to well-developed seta. Maxilliped as in T. (A.) insularis; proximal lobe of syncoxa with short rudimentary element (figure $2 \mathrm{H}$ in Ohtsuka \& Conway, 2003). Legs 1-4 similar to those of others of subgenus (cf. Ohtsuka \& Kimoto, 1989).

Leg 5 (Figure 2I) with both coxae and intercoxal sclerite completely fused to form common base; basis with outer plumose seta subterminally; exopods unisegmented, left slightly longer than right, each with one inner middle and two terminal, acutely pointed processes; terminal processes unequal on left, but almost equal on right.

\section{Description of adult male}

Body (Figure 3A) more slender than that of female; posterior prosome symmetrical, rounded. Urosome (Figure 3B) asymmetrical on genital and first abdominal somites; right side of first abdominal somite produced posterolaterally into triangular knob, bearing short setule at tip.

Right geniculate antennule (Figure 3C) with segmentation and setation as in others of subgenus (see Ohtsuka \& Reid, 1998); distal elements on segments XI and XIV spiniform; distal process on compound segment XXIXXIII (segment posterior to hinge) elongate enough to reach beyond distal tip of antennule. Left antennule reaching beyond posterior end of caudal rami (excluding setae).

Leg 5 (Figure 3D-H) with complex chela on right leg. Right leg (Figure 3D-G) with coxa unarmed; basis massive, tapering proximally, with triangular process bearing two spiniform setae on anterior surface and round, unarmed process on posterior surface; basal seta located midway on posterior surface; exopod unisegmented, with two distinct lobes; anterior lobe triangular, with longitudinal depression housing triangular basal process and three minute setules; posterior lobe rounded, unarmed. Left leg (Figure 3D\&H) with unarmed coxa; basis elongate, with inner seta on knob and outer seta subterminally; exopod 2-segmented; first exopodal segment curved inward with short, stout seta on proximal, lamellar expansion and outer minute setule subterminally; second exopodal segment curved inward, sinuous along inner margin, carrying two small inner setae, two unequal outer setae, and two longitudinal rows of setules and six subterminal and terminal patches of fine setules; terminal part of second segment with serrate lamella and small round prominences; terminal seta serrated along inner margin.

\section{Comparison}

The present new species is readily distinguished from other congeners belonging to the recticauda species group, in the combination of the following features: (1) the largesized, acutely pointed process on the right ventrolateral side of the female genital compound-somite; (2) the asymmetrical caudal rami of the female with the left side more expanded and longer than the right; (3) the fifth leg of the female nearly symmetrical; (4) the distal process on the compound segment distal to hinge of the male right antennule reaching beyond distal tip of terminal segment; (5) the fifth right leg of the male with unique chela.

Among the recticauda species group the female of this new species is most similar to that of $\mathcal{T}$. (A.) recticauda from 


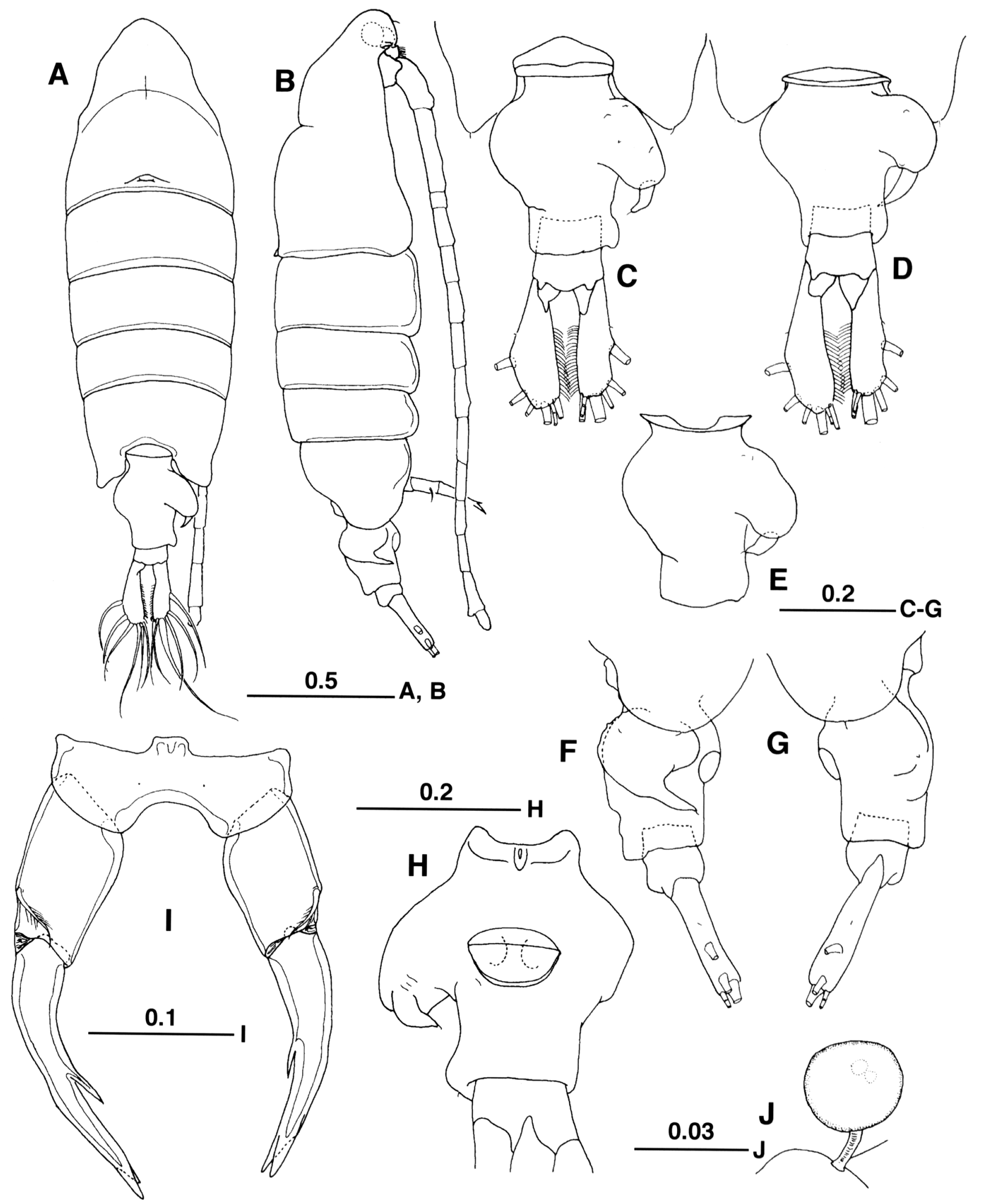

Figure 2. Tortanus (Atortus) magnonyx, sp. nov. Female, holotype (A-C, F-J), paratypes (D, E). (A) Habitus, dorsal view; (B) habitus, lateral view; (C, D) posterior prosome and urosome, dorsal view; (E) genital compound somite, dorsal view; (F) posterior prosome and urosome, right lateral view; $(\mathrm{G})$ posterior prosome and urosome, left lateral view; $(\mathrm{H})$ genital compound and anal somites, ventral view; (I) leg 5, posterior surface; ( $\mathrm{J}$ ) phoront of apostome ciliate on intercoxal sclerite of leg 4. Scale bars in mm. 


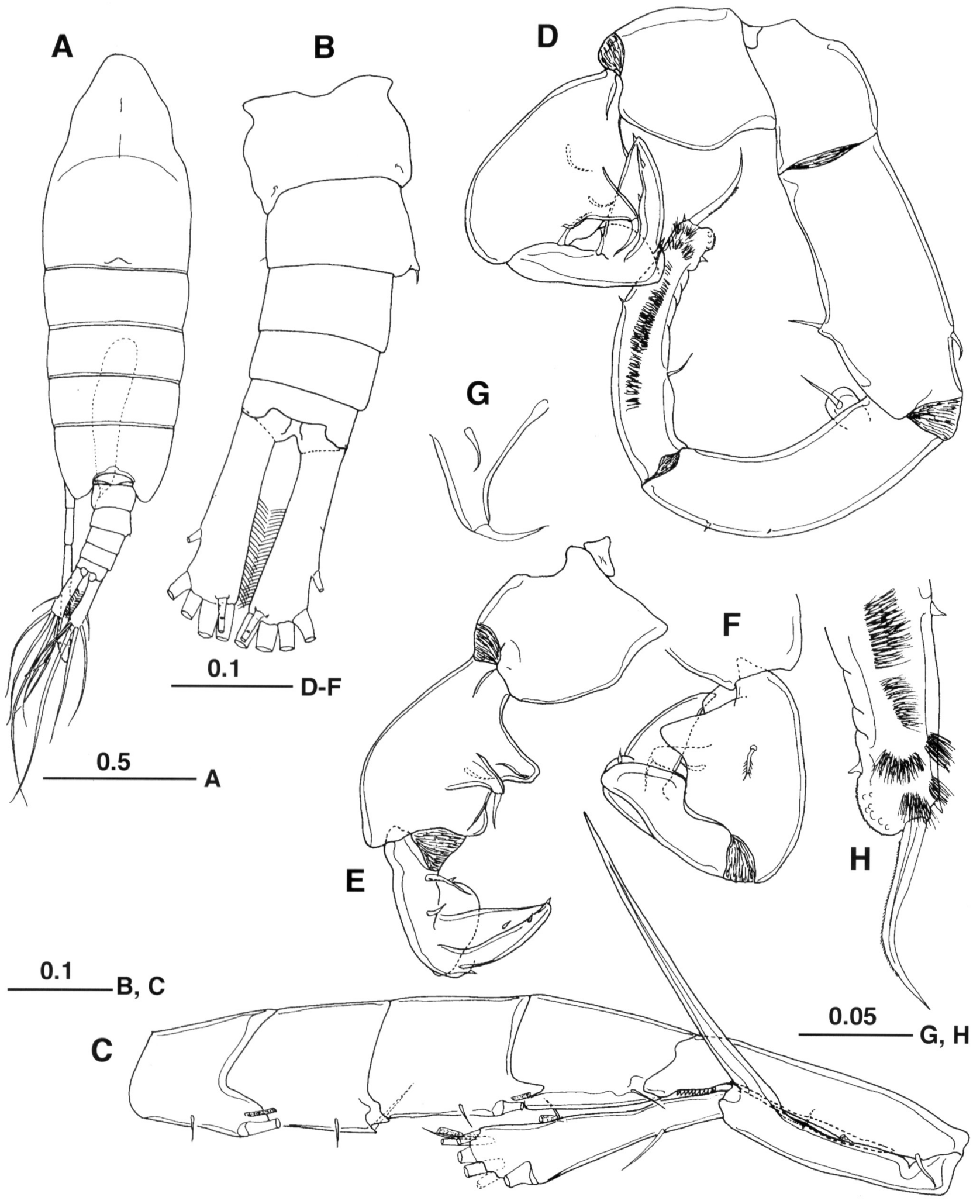

Figure 3. Tortanus (Atortus) magnonyx, sp. nov. Male, allotype (A-D, F-H), paratype (E). (A) Habitus, dorsal view; (B) urosome, dorsal view; $(\mathrm{C})$ right geniculate antennule, segments XVI to XXIV-XXVIII; (D) leg 5, anterior surface; (E) right leg 5, anterior surface; (F) right leg 5, posterior surface; $(\mathrm{G})$ basal process of right leg 5 with one terminal and one proximal setae; $(\mathrm{H})$ terminal portion of left leg 5 . Scale bars in $\mathrm{mm}$. 
the Red Sea and the Arabian Gulf (Giesbrecht, 1892; Bowman, 1986) in bearing a large, curved process on the right side of the female genital compound-somite, the left caudal ramus slightly longer and wider than the right, and nearly symmetrical legs 5 . The male of the new species resembles that of T. (A.) nishidai from the Gulf of Aden (which is only known from the male; Ohtsuka et al., 2000), in bearing the elongate distal process on the compound segment XXI-XXIII of the right antennule, and in the structure of right leg 5 .

\section{Other observations}

Some cysts were observed attached to the swimming legs of T. (A.) magnonyx from Mahé (Figure 2J), each with a short stalk. These were identified as phoronts of apostome ciliates.

It is worth noting that among the copepods sampled at Île Sainte Marie in Madagascar, were a few specimens of T. (A.) insularis, previously only recorded from Rodrigues Island, Mauritius (Ohtsuka \& Conway, 2003).

\section{Etymology}

The specific name of the new species 'magnonyx' (Latin, magnus meaning large, plus onyx meaning claw) alludes to the large-sized process on the right ventrolateral side of the female genital compound-somite.

\section{DISGUSSION}

Until the discovery of Tortanus (Atortus) insularis around the isolated oceanic island of Rodrigues in the western Indian Ocean (Ohtsuka \& Conway, 2003), Tortanus of the recticauda species group had previously only been recorded from the coastal rim of the western Indian Ocean. Tortanus (A.) insularis is now here additionally recorded from Madagascar. The present new species, T. (A.) magnonyx, is also recorded from Madagascar and from two other widely separated islands in the western Indian Ocean, Mauritius and Mahé. In all locations, environmental conditions under which T. (A.) magnonyx was sampled were broadly similar, sheltered shallow productive bays, within fringing reefs. However, the inner part of the bay in Mauritius, where the copepods were collected, was quite eutrophic, probably because it was very sheltered and in close proximity to a settlement. It is not known how far the copepods were distributed seawards at the three locations, but it appears to be a feature of members of the originally coastal sub-genus Atortus that they can tolerate a wide range of salinities, from inshore to oceanic waters, which seems to have allowed them to extend their distributions to these oceanic islands (Ohtsuka \& Conway, 2003).

The open Indian Ocean has been well surveyed for zooplankton (Rao \& Griffiths, 1998), but the inshore areas of the oceanic islands and of many of the rim countries have been poorly studied (Conway, in press). The results obtained from the random sampling carried out for this study, suggest that Tortanus of the recticauda species group could be widely distributed. There may be other species to be found, as was indicated in a copepod study by Gaudy (1967) off Tuléar in south-western Madagascar (Figure 1), who noted that there were speci- mens of three different Tortanus species in his samples that he was unable to identify.

Although the recticauda species complex is widely distributed in the Indo-West Pacific, the murrayi species group, of the same species complex, is clearly confined to the West Pacific, whereas the recticauda species group is confined to the Indian Ocean (Ohtsuka \& Kimoto, 1989; Ohtsuka \& Reid, 1998). Ancestors of these two species groups may have experienced a vicariance event in the Wallacea during the Pleistocene and then have independently evolved into separate species groups in each area, similar to the scenario proposed for pontellid copepods by Fleminger (1986). On morphological grounds, Ohtsuka \& Conway (2003) concluded that T. (A.) insularis from Rodrigues seems to be more closely related to $T$. (A.) recticauda from the Red Sea and Arabian Gulf (Giesbrecht, 1889, 1892), rather than to T. (A.) capensis from South Africa (Grindley, 1978), with which it has a more proximate distribution. The Tortanus (A.) magnonyx female also most closely resembles the female of $\mathcal{T}$. (A.) recticauda, while the male has similarities to the male of $T$. (A.) nishidai from the Gulf of Aden (Ohtsuka et al., 2000). These similarities suggest a closer relationship between the pelagic faunas of the northern Indian Ocean and the western islands, rather than with coastal southern Africa, which may be a reflection of the ancient current system (Ohtsuka \& Conway, 2003).

The mechanisms of zooplankton dispersal and isolation are beginning to be better understood (e.g. Peijnenburg et al., 2004) and it can be concluded that at least some inshore species drift passively and regularly between locations (Barber et al., 2002). The Tortanus species that have been sampled around oceanic islands, T. (A.) insularis and now T. (A.) magnonyx, are predatory inshore species. Little research has been carried out on the biology of Tortanus species, but during their life cycle they may be quite dependent on shallow water, given the Tortanidae habit of laying resting eggs which sink to the sediments (Marcus, 1996). Thus natural dispersion over great distances could be problematical for them. Our knowledge of the distribution of the recticauda species group is currently too incomplete to make any conclusions on how they were dispersed and subsequently speciated in the Indian Ocean. However, developments in molecular systematic analysis have allowed examination of phylogenetic relationships between a range of copepod species (Bucklin et al., 2003) and specimens of Tortanus have been collected for genetic analysis from some of the sites, to examine relationships between members of the same genera or species group, at the same or separate locations. These data could indicate how long since they diverged from a common ancestor, whether there is regular exchange of genetic material between isolated populations of the same species and may give clues to how they spread.

The presence of apostome phoronts on the swimming legs of $\mathcal{T}$. (A.) magnonyx is interesting, as these were also recorded from some shallow- and deep-water planktonic copepods in the Arabian Sea (Sewell, 1951). According to Ohtsuka et al. (2004), apostomes are likely to play an important ecological role as histophagous ciliates round the coast of western Japan and may thus also be important around the oceanic islands of the Indian Ocean. 
Taxonomic work was partially supported by a grant-in-aid from the Japanese Society for the Promotion of Science (JSPS), awarded to S.O. (no. 14560151). D.C. would like to thank the UK Department for Environment Food and Rural Affairs (Defra), Darwin Initiative Project, for funding the Indian Ocean zooplankton sampling programme, staff at the Seychelles Centre for Marine Research and Technology - Marine Parks Authority for their support and the other UK team members involved in the project, Rowena White (affiliated to the University of Wales, Bangor), Dave Robins, Chris Gallienne and Joanna Hugues-DitCiles (Plymouth Marine Laboratory). Appreciation is also given to the islanders of Île Sainte Marie for the enthusiastic interest shown during the sampling from their causeway.

\section{REFERENCES}

Barber, P.H., Moosa, M.K. \& Palumbi, S.R., 2002. Rapid recovery of genetic diversity of stomatopod populations on Krakatau: temporal and spatial scale of marine larval dispersal. Proceedings of the Royal Society B, 269, 1591-1597.

Bowman, T.E., 1986. Tortanus recticauda: extension of range to Arabian Gulf (Copepoda, Calanoida, Tortanidae). Crustaceana, 50, 239-242.

Bucklin, A., Frost, B.W., Bradford-Grieve, J., Allen, L.D. \& Copley, N.J., 2003. Molecular systematic and phylogenetic assessment of 34 calanoid copepod species of the Calanidae and Clausocalanidae. Marine Biology, 142, 333-343.

Burnett, J.C., Kavanagh, J.S. \& Spencer, T., 2001. Marine science, training and education in the western Indian Ocean. Shoals of Capricorn Programme Field Report 1998-2001. London: Royal Geographical Society (with The Institute of British Geographers).

Conway, D.V.P., in press. Island-coastal and oceanic epipelagic zooplankton biodiversity in the southwestern Indian Ocean. Indian Fournal of Marine Sciences.

Conway, D.V.P., White, R.G., Hugues-Dit-Ciles, J., Gallienne, C.P. \& Robins, D.B., 2003. Guide to the coastal and surface zooplankton of the south-western Indian Ocean. Marine Biological Association of the United Kingdom, Plymouth, Occasional Publication, no. 15, 354 pp.

Fleminger, A., 1986. The Pleistocene equatorial barrier between the Indian and Pacific Oceans and a likely cause for Wallace's Line. UNESCO Technical Papers in Marine Science, 49, 84-97.

Gaudy, R., 1967. Note préliminaire sur la systématique et la répartition annuelle des copépods des eaux superficielles de Tulear (Madagascar). Recueil des Travaux de la Station Marine d'Endoume, Fasicule Hors Série Supplement no. 6, 71-99.
Giesbrecht, W., 1889. Elenco dei Copepodi pelagici raccolti dal Tenente di vascello Gaetano Chierchia durante il viaggio della R. Corvetta 'Vettor Pisani' negli anni 1882-1885 e dal Tenente di vascello Francesco Orsini nel Mar Rosso, nel 1884. Atti della Accademia Nazionale dei Lincei, 5, 24-29.

Giesbrecht, W., 1892. Systematik und Faunistik der pelagischen Copepoden des Golfes von Neapel und der angrenzenden Meeres-Abschnitte. Fauna Flora des Golfes von Neapel, 19, 1-831.

Grindley, J.R., 1978. A new species of Tortanus (Crustacea, Copepoda) from South Africa. Annals of the South African Museum, 74, 219-228.

Huys, R. \& Boxshall, G.A., 1991. Copepod evolution. London: The Ray Society.

Marcus, N.H., 1996. Ecological and evolutionary significance of resting eggs in marine copepods: past, present, and future studies, Hydrobiologia, 320, 141-152.

Ohtsuka, S. \& Conway, D.V.P., 2003. A new species of Tortanus (Atortus) (Copepod: Calanoida: Tortanidae) from Rodrigues Island, Mauritius. Fournal of the Marine Biological Association of the United Kingdom, 83, 355-360.

Ohtsuka, S., El-Sherbiny, M.M. \& Ueda, H., 2000. Taxonomy, functional morphology, and behavioral ecology of the planktonic calanoid copepod Tortanus (Atortus). Crustacean Research, 29, 1-11.

Ohtsuka, S., Hora, M., Suzaki, T., Arikawa, G., Omura, G. \& Yamada, K., 2004. Morphology and host-specificity of the apostome ciliate Vampyrophrya pelagica infecting pelagic copepods in the Seto Inland Sea, Japan. Marine Ecology Progress Series, 282, 129-142.

Ohtsuka, S. \& Kimoto, K., 1989. Tortanus (Atortus) (Copepoda: Calanoida) of southern Japanese waters, with description of two new species, T. (A.) digitalis and T. (A.) ryukyuensis, and discussion on distribution and swarming behavior of Atortus. Fournal of Crustacean Biology, 9, 392-408.

Ohtsuka, S. \& Reid, J.W., 1998. Phylogeny and zoogeography of the planktonic copepod genus Tortanus (Calanoida: Tortanidae), with establishment of a new subgenus and descriptions of two new species. Fournal of Crustacean Biology, 18, 774-807.

Peijnenburg, K.T.C.A., Breeuwer, J.A.J., Pierrot-Bults, A.C. \& Menken, S.B.J., 2004. Phylogeography of the planktonic chaetognath Sagitta setosa reveals isolation in European seas. Evolution, 58, 1472-1487.

Rao, T.S.S. \& Griffiths, C., 1998. Understanding the Indian Ocean. Perspectives on oceanography. Paris: UNESCO.

Sewell, R.B.S., 1951. The epibionts and parasites of the planktonic Copepoda of the Arabian Sea. Scientific Report of John Murray Expedition, 9, 255-394.

Submitted 31 August 2004. Accepted 11 January 2005. 